\title{
Drug utilization pattern in four major wards of a tertiary hospital in eastern Nepal
}

\author{
DP Sarraf, GP Rauniar, A Misra \\ Department of Clinical Pharmacology and Therapeutics \\ B.P. Koirala Institute of Health Sciences, Dharan, Nepal
}

\begin{abstract}
Background: Drugs play an important role in protecting, maintaining and restoring health. Drugs are prescribed irrationally throughout the world. Objective: To study the utilization of drugs in in-patient of four major ward of a tertiary care hospital in Nepal. Method: This was a cross-sectional descriptive study conducted in four major wards for duration of one month. Result: A total of 467 patients were prescribed a total of 2188 drugs among which 535 drugs were prescribed in surgery ward, 567 drugs in medicine ward, 220 drugs in pediatric ward and 866 drugs in obstetrics and gynecology ward. The average number of drugs per prescription was 4.68. All drugs were prescribed by brand names and generic prescribing was nil. Among all, $70.61 \%$ of drugs were from essential list of drugs.43.87\% of drugs were given through injections. $34.41 \%, 26.05 \%, 11.7 \%, 6.35 \%, 6.17 \%$ and $4.84 \%$ of prescribed drugs were AMA, GIT, MSK, CNS, CVS and minerals and vitamins respectively. Four drugs per prescription were prescribed to $21.41 \%$ of the total patients $(n=467)$. Conclusion: Polypharmacy, low rate of generic prescriptions and overuse of antibiotics still remain a problem in health care facilities in Nepal. This calls for sustained interventional strategies and periodic audit at all levels of health care to avoid the negative consequences of inappropriate prescriptions.
\end{abstract}

Keywords: Essential drugs, generic drugs, Nepal, prescribing pattern, tertiary hospital,

\section{Introduction}

World Health Organization (WHO) has defined rational use of drugs as "patients receive medicines appropriate to their clinical needs, in doses that meet their own individual

Address for correspondence

Dr. Deependra Prasad Sarraf

Assistant Professor

Department of Clinical Pharmacology and Therapeutics

B.P. Koirala Institute of Health Sciences, Dharan

Email: deependraprasadsarraf@gmail.com requirements for an adequate period of time, at the lowest cost to them and their community". ${ }^{1}$ Drugs play an important role in protecting, maintaining and restoring health. Drugs are prescribed irrationally throughout the world. Polypharmacy is the most common irrational practice which is also common in developed and developing countries. ${ }^{2}$ Irrational prescription of drugs may cause 
delay in relief, more adverse effects, prolonged hospitalization, increased morbidity and mortality, emergence of microbial resistance, financial loss to patient and community and perpetuation of public health problem. $^{3}$

Drug utilization research defined as the marketing, distribution, prescription and use of drugs in a society with special emphasis on the resulting medical, social and economic consequences is one of the approaches for studying medicine use. Drug utilization research is done to assess whether drug therapy is rational or not. Drug utilization research can be divided into descriptive and analytical studies. The descriptive study describes patterns of drug utilization and identifies problems deserving more detailed studies. Analytical studies try to link data on drug utilization to figures on morbidity, outcome of treatment, and quality of care, with the ultimate goal to assess whether drug therapy is rational or not. Drug utilization research also provides insight into the efficiency of drug use, i.e. whether a certain drug therapy provides value for money and the results of such research are used to help to set priorities for the rational allocation of health care budgets. ${ }^{4}$

Scope of drug utilization research is to evaluate not only trends of drug usage but also appropriateness of prescriptions and adherence to evidence based recommendations. Information from these drug use measures can also be used by health planners and prescribers to outline newer guidelines for standard efficient therapy. Drug utilization studies can be used as a tool for evaluation of health care system since such type of studies provide information regarding prevailing trend of rational and irrational medication in a particular region. ${ }^{5}$

The introduction of the Core Drug Use Indicators (CDUIs) following the collaborative work by the members of the International Network for Rational Use of Drugs (INRUD) and the Drug Action Programme -WHO (DAP-WHO) regarded as one of the most notable achievements in the orchestrated effort at promoting rational use of drugs. These indicators are highly standardized, do not need national adaptation and provide a simple tool for quickly and reliably assessing a few critical aspect of drug use in primary health care setup. ${ }^{6}$ There are three types of CDUIs; these are prescribing indicators, patient care indicators and facility indicators. ${ }^{7}$ Among these, prescribing indicators are most commonly used in drug utilization research and are average number of drugs per prescription, percentage of drugs prescribed by generic name, percentage of prescription with an antibiotic prescribed, percentage of prescription with an injection prescribed and percentage of drugs prescribed from an Essential Drugs List (EDL). 
Drug utilization patterns need to be evaluated from time to time so as to increase the therapeutic efficacy, decrease the adverse effects and to provide feedback to the prescribers to create awareness towards rational use of drugs. Although many studies are conducted in Nepal regarding prescription pattern but prevalent of irrationality in prescription may not be the same in different regions of Nepal. Hence, the present study was carried out to evaluate the prescription pattern in four major departments of a tertiary hospital in eastern Nepal which covers urban and rural population with the aim to find out the utilization of drugs in in-patient of four major wards of a tertiary care hospital.

\section{Methods}

BPKIHS is deemed university of Nepal. The hospital has 700 beds most of which is occupied by four major departments like medicine, surgery, pediatric and obstetrics and gynecology. The wards were visited daily. The pattern of drug utilization was recorded prospectively from the case records of in-patients for a period of one month (from February 24, 2011 to March 26, 2011). The following data collected for the study included patient demographics, and prescription information such as drug name and date of prescription. The data was collected on a specially designed proforma.

Each drug or drug preparation used was counted as one and the number of prescriptions for a particular drug was used to express the frequency of the drug use. Intravenous fluids and blood transfusion were not counted as drugs. Each drug prescribed was recorded including its dosage form, route of administration, frequency of administration, indications for use, and duration of therapy. The data then was evaluated by Microsoft Excel software (MS office version 2013) for analysis and descriptive statistics.

\section{Results}

Total of 467 patients were admitted to the major wards during the research period of one month. The number of male and female patients were 156 (33.5\%) and 311 (66.5\%) respectively. The ratio of male to female was $1: 2$. Maximum number of patient (43\%) was admitted to obstetrics and gynecology ward followed by surgery ward (22\%), medicine ward $(20 \%)$ and pediatric ward (15\%). The average duration of their hospital stay was 5.41days (Table 1).

\section{Table 1: Numbers of patients}




\begin{tabular}{|l|l|l|l|l|}
\hline \multicolumn{1}{|c|}{ Departments } & \multicolumn{1}{|c|}{$\begin{array}{c}\text { No. of } \\
\text { patients }\end{array}$} & Male & Female & $\begin{array}{c}\text { Total days stay in hospital } \\
\text { (average stay) }\end{array}$ \\
\hline Medicine & 93 & 50 & 43 & $606(6.52)$ \\
\hline Pediatrics & 70 & 36 & 34 & $383(5.47)$ \\
\hline Surgery & 105 & 70 & 35 & $633(6.03)$ \\
\hline Obstetrics and Gynecology & 199 & - & 199 & $907(4.56)$ \\
\hline Total & $\mathbf{4 6 7}$ & $\mathbf{1 5 6}$ & $\mathbf{3 1 1}$ & $2529(5.41)$ \\
\hline
\end{tabular}

Most of the patient in all major departments was from Sunsari district $(48.39 \%)$, followed by Morang district (17.77\%) and Jhapa district (7.71\%) (Figure 1).

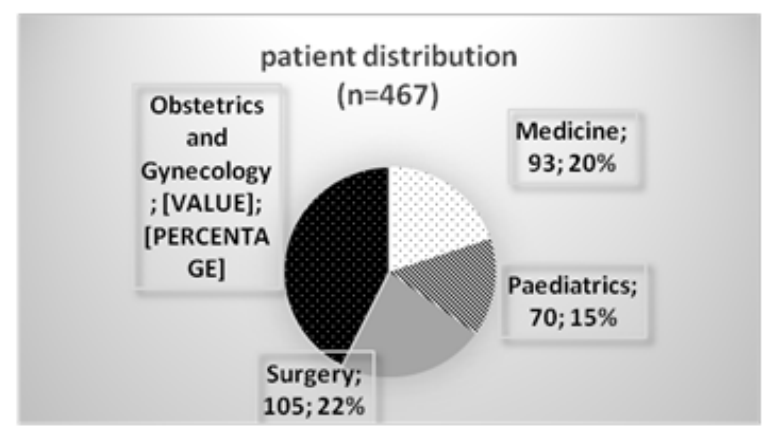

Fig. 1: Patient distribution

All the 467 patients received a total of 2188 drugs among which 535 drugs were prescribed in surgery, 567 drugs in medicine, 220 drugs in pediatric and 866 drugs in obstetrics and gynecology ward. Antimicrobial agents (AMA) were most commonly drug prescribed (34.41\%) followed by gastrointestinal (GIT) drugs (26.05\%), musculoskeletal (MSK) drugs (11.70\%), CNS drugs $(6.35 \%)$, cardiovascular (CVS) drugs (6.17\%) and minerals and vitamins (4.84\%). $\%)$. In surgery ward, AMA was second most commonly prescribed (34.95\%) followed by GIT drugs (24.48\%), MSK drugs (19.06\%) and CNS drugs (11.21\%). In medicine ward, GIT drugs were most commonly prescribed (29.45\%) followed by AMA (28.21\%), CVS drugs $(17.98 \%)$, respiratory drugs $(7.05 \%)$, minerals and vitamins (5.64\%) and CNS drugs $(5.29 \%)$. AMA were most commonly prescribed in pediatric ward (49.54\%) followed by CNS drugs (12.27\%), GIT drugs (11.82\%) and respiratory drugs (11.36\%). In obstetrics and gynecology ward, AMA were most commonly prescribed drugs followed by GIT (28.41\%), MSK drugs (16.63\%) and minerals and vitamins (5.31\%) (Table 2).

Table 2: Prescribing frequency of drugs according to drug class 


\begin{tabular}{|c|c|c|c|c|c|c|c|c|c|c|}
\hline \multirow[t]{2}{*}{$\begin{array}{l}\text { Type of } \\
\text { drugs }\end{array}$} & \multicolumn{2}{|c|}{$\begin{array}{l}\text { Surgery } \\
(n=105)\end{array}$} & \multicolumn{2}{|c|}{$\begin{array}{l}\text { Medicine } \\
\qquad(n=93)\end{array}$} & \multicolumn{2}{|c|}{$\begin{array}{l}\text { Pediatrics } \\
(n=70)\end{array}$} & \multicolumn{2}{|c|}{$\begin{array}{c}\text { Obst/Gynae } \\
(n=199)\end{array}$} & \multicolumn{2}{|c|}{ Overall } \\
\hline & $\begin{array}{l}\text { No. of } \\
\text { drugs }\end{array}$ & $\%$ & $\begin{array}{l}\text { No. of } \\
\text { drugs }\end{array}$ & $\%$ & $\begin{array}{l}\text { No. of } \\
\text { drugs }\end{array}$ & $\%$ & $\begin{array}{l}\text { No. of } \\
\text { drugs }\end{array}$ & $\%$ & $\begin{array}{l}\text { No. of } \\
\text { drugs }\end{array}$ & $\%$ \\
\hline AMA & 187 & 34.95 & 160 & 28.21 & 109 & 49.54 & 297 & 34.29 & 753 & 34.41 \\
\hline GIT & 131 & 24.48 & 167 & 29.45 & 26 & 11.82 & 246 & 28.41 & 570 & 26.05 \\
\hline MSK & 102 & 19.06 & 9 & 1.58 & 1 & 0.45 & 144 & 16.63 & 256 & 11.70 \\
\hline CNS & 60 & 11.21 & 30 & 5.29 & 27 & 12.27 & 22 & 2.54 & 139 & 6.35 \\
\hline CVS & 9 & 1.68 & 102 & 17.98 & 9 & 4.09 & 15 & 1.73 & 135 & 6.17 \\
\hline $\begin{array}{l}\text { Minerals \& } \\
\text { vitamins }\end{array}$ & 9 & 1.68 & 32 & 5.64 & 19 & 8.64 & 46 & 5.31 & 106 & 4.84 \\
\hline $\begin{array}{l}\text { Respiratory } \\
\text { system }\end{array}$ & 8 & 1.49 & 40 & 7.05 & 25 & 11.36 & 13 & 1.50 & 86 & 3.93 \\
\hline Others & 29 & 5.42 & 27 & 4.76 & 4 & 1.81 & 83 & 9.58 & 249 & 6.53 \\
\hline Total & 535 & 100 & 567 & 100 & 220 & 100 & 866 & 100 & 2188 & 100 \\
\hline
\end{tabular}

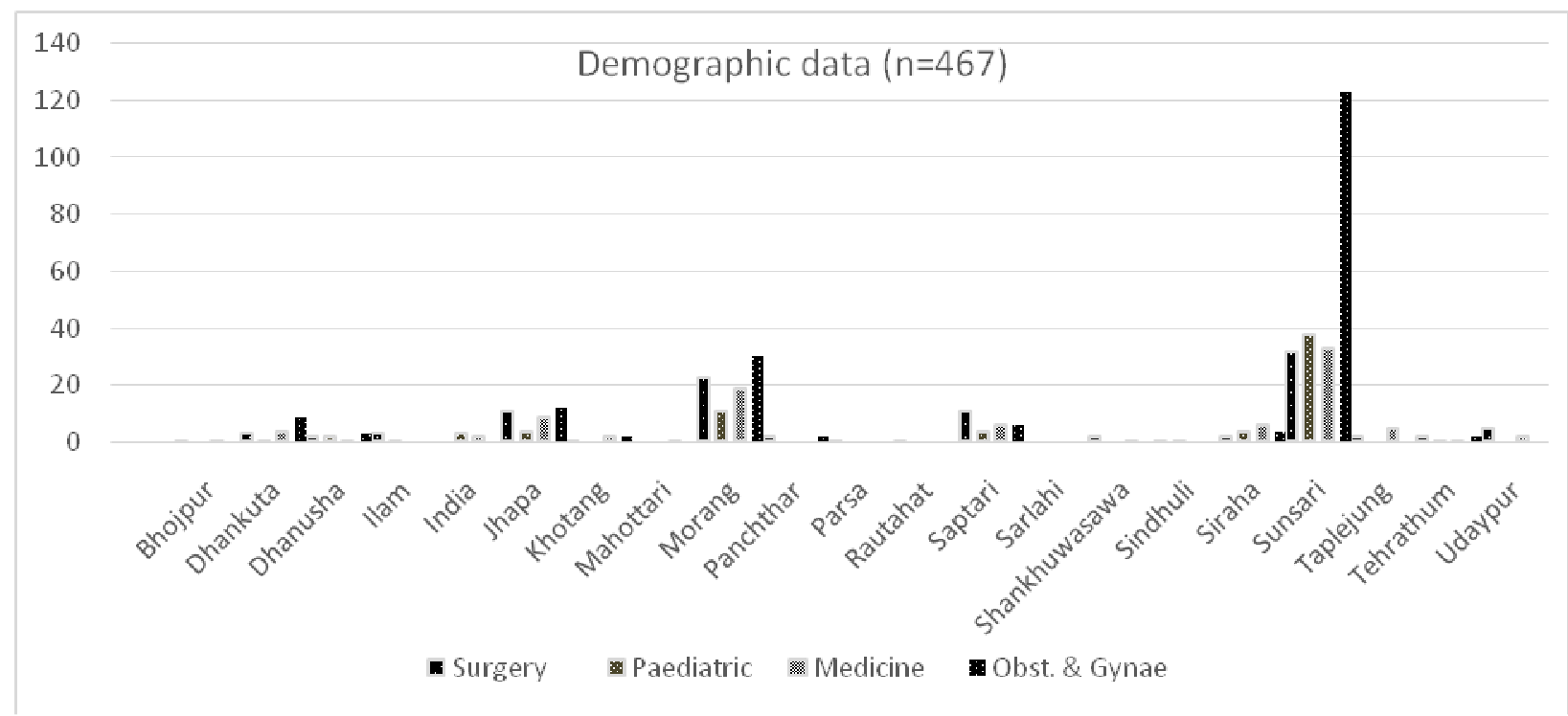

Fig. 2: Demographic data

Oral route was most commonly used route for drug administration in all wards except pediatric in which intravenous route was most common. Most of the drugs were given 
through oral route $(54.62 \%)$, followed by (10.6\%). $43.87 \%$ of all drugs were given intravenous (32.72\%) and intramuscular route through injection (Table 3).

Table 3: Major routes of drug administration

\begin{tabular}{|l|l|l|l|l|l|l|l|l|l|l|}
\hline \multirow{2}{*}{ Route } & \multicolumn{2}{|c|}{ Surgery } & \multicolumn{2}{c|}{ Medicine } & \multicolumn{2}{c|}{ Pediatrics } & \multicolumn{2}{c|}{ Obst/gynae } & \multicolumn{2}{c|}{ Overall } \\
\cline { 2 - 12 } & $\begin{array}{l}\text { No. of } \\
\text { drugs }\end{array}$ & $\%$ & $\begin{array}{l}\text { No. of } \\
\text { drugs }\end{array}$ & $\%$ & $\begin{array}{l}\text { No. of } \\
\text { drugs }\end{array}$ & $\%$ & $\begin{array}{l}\text { No. of } \\
\text { drugs }\end{array}$ & $\begin{array}{l}\text { No. of } \\
\text { drugs }\end{array}$ & $\%$ \\
\hline Oral & 234 & 43.74 & 373 & 65.78 & 89 & 40.45 & 499 & 57.62 & 1195 & 54.62 \\
\hline IV & 195 & 36.45 & 147 & 25.93 & 96 & 43.63 & 278 & 32.10 & 716 & 32.72 \\
\hline IM & 103 & 19.25 & 26 & 4.59 & 19 & 8.63 & 84 & 9.69 & 232 & 10.60 \\
\hline SC & 1 & 0.185 & 8 & 1.41 & 3 & 1.36 & 0 & 0 & 12 & 0.54 \\
\hline Inhalation & 0 & 0 & 7 & 1.23 & 12 & 5.45 & 1 & 0.12 & 20 & 0.91 \\
\hline others & 2 & 0.37 & 6 & 1.06 & 1 & 0.45 & 4 & 0.47 & 13 & 0.61 \\
\hline Total & 535 & 100 & 567 & 100 & 220 & 100 & 866 & 100 & 2188 & 100 \\
\hline
\end{tabular}

Among 2188 drugs, $27.46 \%$ and $22.62 \%$ were administered three times daily and twice daily respectively. Three times daily was the most common frequency of drug administration in all wards except medicine in which most drugs were given twice daily (Table 4).

Table 4: Frequency of drug administration

\begin{tabular}{|l|l|l|l|l|l|l|l|l|l|l|}
\hline \multirow{2}{*}{ Frequency } & \multicolumn{2}{|c|}{ Surgery } & \multicolumn{2}{c|}{ Medicine } & \multicolumn{2}{c|}{ Pediatrics } & \multicolumn{2}{c|}{ Obst/gynae } & \multicolumn{2}{c|}{ Overall } \\
\cline { 2 - 12 } & $\begin{array}{l}\text { No. of } \\
\text { drugs }\end{array}$ & $\%$ & $\begin{array}{l}\text { No. of } \\
\text { drugs }\end{array}$ & $\%$ & $\begin{array}{l}\text { No. of } \\
\text { drugs }\end{array}$ & $\begin{array}{l}\text { No. of } \\
\text { drugs }\end{array}$ & $\begin{array}{l}\text { No. of } \\
\text { drugs }\end{array}$ & $\%$ \\
\hline BD & 161 & 30.09 & 165 & 29.10 & 40 & 18.18 & 129 & 14.89 & 495 & 22.62 \\
\hline TDS & 182 & 34.02 & 125 & 22.05 & 52 & 23.63 & 242 & 27.94 & 601 & 27.46 \\
\hline Stat & 50 & 9.35 & 41 & 7.23 & 27 & 12.27 & 128 & 14.78 & 246 & 11.24 \\
\hline OD & 49 & 9.16 & 154 & 27.16 & 24 & 10.90 & 160 & 18.47 & 387 & 17.69 \\
\hline SOS & 26 & 4.86 & 28 & 4.94 & 12 & 5.45 & 31 & 3.58 & 97 & 4.43 \\
\hline Others & 67 & 12.52 & 54 & 9.53 & 65 & 29.52 & 176 & 20.32 & 362 & 16.54 \\
\hline Total & 535 & 100 & 567 & 100 & 220 & 100 & 866 & 100 & 2188 & 100 \\
\hline
\end{tabular}


$65.67 \%, \quad 44.73 \%, \quad 62.86 \%$ and $57.59 \%$ patients were prescribed 3-4 drugs in surgery, medicine and pediatrics and obstetrics and gynecology wards respectively. $1.93 \%$ patients were prescribed no drug as their investigation results were awaited during the study period. Most of the patients $(21.41 \%)$ were prescribed four drugs per prescription. $47.31 \%$ patient in medicine ward were prescribed more than five drugs. More than five drugs were prescribed in $18.84 \%$ patients $(n=467)$ (Table 5 ).

Table 5: Number of drug prescribed per patients

\begin{tabular}{|c|c|c|c|c|c|c|c|c|c|c|}
\hline \multirow{2}{*}{$\begin{array}{l}\text { No. of } \\
\text { drugs } \\
\text { per } \\
\text { patient }\end{array}$} & \multicolumn{2}{|c|}{ Surgery } & \multicolumn{2}{|c|}{ Medicine } & \multicolumn{2}{|c|}{ Pediatrics } & \multicolumn{2}{|c|}{ Obst/gynae } & \multicolumn{2}{|c|}{ overall } \\
\hline & $\begin{array}{l}\text { No. of } \\
\text { patients }\end{array}$ & $\%$ & $\begin{array}{l}\text { No. of } \\
\text { patients }\end{array}$ & $\%$ & $\begin{array}{c}\text { No. of } \\
\text { patients }\end{array}$ & $\%$ & $\begin{array}{l}\text { No. of } \\
\text { patients }\end{array}$ & $\%$ & $\begin{array}{l}\text { No. of } \\
\text { patients }\end{array}$ & $\%$ \\
\hline zero & 3 & 2.86 & 1 & 1.08 & 5 & 7.14 & 0 & 0 & 9 & 1.93 \\
\hline One & 5 & 4.77 & 6 & 6.45 & 5 & 7.14 & 16 & 8.04 & 32 & 6.85 \\
\hline Two & 8 & 7.61 & 9 & 9.68 & 12 & 17.14 & 44 & 22.12 & 73 & 15.63 \\
\hline Three & 26 & 24.77 & 12 & 12.9 & 20 & 28.57 & 33 & 16.58 & 91 & 19.49 \\
\hline Four & 19 & 18.09 & 11 & 11.83 & 16 & 22.86 & 54 & 27.13 & 100 & 21.41 \\
\hline Five & 24 & 22.81 & 10 & 10.75 & 8 & 11.43 & 32 & 16.08 & 74 & 15.85 \\
\hline$>$ Five & 20 & 19.04 & 44 & 47.31 & 4 & 5.72 & 20 & 10.05 & 88 & 18.84 \\
\hline Total & 105 & 100 & 93 & 100 & 70 & 100 & 199 & 100 & 467 & 100 \\
\hline
\end{tabular}

Among all prescription drugs, $43.87 \%$ were given through injections; $14.39 \%$ were analgesics; $15.95 \%$ were minerals and vitamins; $34.41 \%$ were AMA. Most of the drugs $(70.61 \%)$ prescribed were from the Essential drug list of Nepal. None of the drugs were prescribed by generic name (Table 6a).

Table 6a: Prescribing indicators

\begin{tabular}{|l|c|c|c|c|c|}
\hline Prescribing & Surgery & Medicine & Pediatrics & Obst/gynae & Overall \\
\hline
\end{tabular}




\begin{tabular}{|c|c|c|c|c|c|c|c|c|c|c|}
\hline \multirow[t]{2}{*}{ indicators } & \multicolumn{2}{|c|}{$\begin{array}{c}(\mathrm{n}=105, \text { total } \\
\text { drug } \\
\text { prescribed= } \\
535)\end{array}$} & \multicolumn{2}{|c|}{$\begin{array}{c}\text { (n=93, total } \\
\text { drug } \\
\text { prescribed= } \\
567)\end{array}$} & \multicolumn{2}{|c|}{$\begin{array}{c}(\mathrm{n}=70, \text { total } \\
\text { drug } \\
\text { prescribed= } \\
220)\end{array}$} & \multicolumn{2}{|c|}{$\begin{array}{l}(n=199, \text { total drug } \\
\text { prescribed }=866)\end{array}$} & \multicolumn{2}{|c|}{$\begin{array}{c}\begin{array}{c}(n=467, \text { total } \\
\text { drug }\end{array} \\
\text { prescribed } \\
=2188)\end{array}$} \\
\hline & No. & $\%$ & No. & $\%$ & No. & $\%$ & No. & $\%$ & No. & $\%$ \\
\hline $\begin{array}{l}\text { Total no. of } \\
\text { Injection }\end{array}$ & 299 & 55.89 & 181 & 31.92 & 118 & 53.63 & 362 & 41.80 & 960 & 43.87 \\
\hline $\begin{array}{l}\text { Total no. of } \\
\text { Analgesic }\end{array}$ & 116 & 21.68 & 21 & 3.70 & 18 & 8.18 & 160 & 18.47 & 315 & 14.39 \\
\hline $\begin{array}{l}\text { Total no. of } \\
\text { Vitamins/ } \\
\text { minerals }\end{array}$ & 31 & 5.79 & 72 & 12.69 & 32 & 14.54 & 214 & 24.71 & 349 & 15.95 \\
\hline $\begin{array}{l}\text { Total no. of } \\
\text { AMA }\end{array}$ & 187 & 34.95 & 160 & 28.21 & 109 & 49.54 & 297 & 34.29 & 753 & 34.41 \\
\hline $\begin{array}{l}\text { Total no. of } \\
\text { Generic } \\
\text { drug }\end{array}$ & 0 & & 0 & & 0 & & & 0 & 0 & \\
\hline $\begin{array}{l}\text { Total no. of } \\
\text { EDL }\end{array}$ & 453 & 84.67 & 419 & 73.90 & 171 & 77.73 & 502 & 57.97 & 1545 & 70.61 \\
\hline
\end{tabular}

All the 467 patients were prescribed a total of 2188 drugs with mean drugs per patient being 5.09 in surgery, 6.09 in medicine, 3.14 in pediatrics, and 4.35 in obstetrics and gynecology ward respectively. The overall mean drug per patient was 4.68. Almost all patients were prescribed at least one antibiotic and two injections (Table 6b).

Table 6b: Prescribing indicators 


\begin{tabular}{|c|c|c|c|c|c|}
\hline Parameter & $\begin{array}{c}\text { Surgery } \\
\text { ( } n=105, \text { total } \\
\text { drug } \\
\text { prescribed= } \\
535)\end{array}$ & $\begin{array}{l}\text { Medicine } \\
\text { ( } n=93, \text { total } \\
\text { drug } \\
\text { prescribed } \\
=567 \text { ) }\end{array}$ & $\begin{array}{l}\text { Pediatrics } \\
\text { ( } n=70, \text { total } \\
\text { drug } \\
\text { prescribed } \\
=220 \text { ) }\end{array}$ & $\begin{array}{l}\text { Obst/gynae } \\
(\mathrm{n}=199, \\
\text { total drug } \\
\text { prescribed } \\
\quad=866)\end{array}$ & $\begin{array}{l}\text { Overall } \\
(\mathrm{n}=467, \\
\text { total drug } \\
\text { prescribed } \\
\quad=2188)\end{array}$ \\
\hline $\begin{array}{l}\text { Mean no. of } \\
\text { drug/patient }\end{array}$ & 5.09 & 6.09 & 3.14 & 4.35 & 4.68 \\
\hline $\begin{array}{l}\text { Mean no. of } \\
\text { Injection/patient }\end{array}$ & 2.84 & 1.94 & 1.68 & 1.81 & 2.05 \\
\hline $\begin{array}{l}\text { Mean no. of } \\
\text { analgesic/patient }\end{array}$ & 1.10 & 0.22 & 0.25 & 0.80 & 0.67 \\
\hline $\begin{array}{l}\text { Mean no. of } \\
\text { Vitamin/patient }\end{array}$ & 0.29 & 0.77 & 0.45 & 1.07 & 0.74 \\
\hline $\begin{array}{l}\text { Mean no. of AMA/ } \\
\text { patient }\end{array}$ & 1.78 & 1.72 & 1.55 & 1.49 & 1.61 \\
\hline
\end{tabular}

Diclofenac, ranitidine, gentamicin and ampicillin were the most commonly prescribed drugs in surgery, medicine, pediatrics and obstetrics and gynecology respectively. In surgery ward, diclofenac $(17.19 \%)$ was most commonly prescribed followed by ranitidine (16.26\%) and ciprofloxacin $(15.88 \%)$. In medicine ward, ranitidine $(9.35 \%)$ was most commonly prescribed followed by vitamin B complex
$(6.87 \%)$ and frusemide $(5.11 \%)$. In pediatric ward, gentamicin $(12.73 \%)$ was the most commonly prescribed followed by ampicillin (8.63\%) and crystalline Penicillin (8.63\%). In obstetrics and gynecology ward, ampicillin (16.86\%) was most commonly prescribed followed by vitamin B complex (10.51\%), calcium, diclofenac and metronidazole (8.89\% each) (Table 7$)$.

\section{Table 7: Top five drugs prescribed by individual department}




\begin{tabular}{|c|c|c|c|c|}
\hline S.N. & $\begin{array}{c}\text { Surgery } \\
\text { ( } n=105, \text { total drug } \\
\text { prescribed }=535 \text { ) }\end{array}$ & $\begin{array}{c}\text { Medicine } \\
\text { ( } \mathrm{n}=93 \text {, total drug } \\
\text { prescribed }=567 \text { ) }\end{array}$ & $\begin{array}{c}\text { Pediatrics } \\
(\mathrm{n}=70, \text { total drug } \\
\text { prescribed }=220)\end{array}$ & $\begin{array}{c}\text { Obst/gynae } \\
(\mathrm{n}=199, \text { total drug } \\
\text { prescribed }=866)\end{array}$ \\
\hline 1 & $\begin{array}{l}\text { Diclofenac } \\
92(17.19 \%)\end{array}$ & $\begin{array}{l}\text { Ranitidine } \\
53(9.35 \%)\end{array}$ & $\begin{array}{l}\text { Gentamicin } \\
28(12.73 \%)\end{array}$ & $\begin{array}{l}\text { Ampicillin } \\
146(16.86 \%)\end{array}$ \\
\hline 2 & $\begin{array}{l}\text { Ranitidine } \\
87(16.26 \%)\end{array}$ & $\begin{array}{l}\text { Vit B Complex } \\
39(6.87 \%)\end{array}$ & $\begin{array}{l}\text { Ampicillin } \\
19(8.63 \%)\end{array}$ & $\begin{array}{l}\text { Vitamin B Complex } \\
91(10.51 \%)\end{array}$ \\
\hline 3 & $\begin{array}{l}\text { Ciprofloxacin } \\
85(15.88 \%)\end{array}$ & $\begin{array}{l}\text { Frusemide } \\
29(5.11 \%)\end{array}$ & $\begin{array}{l}\text { Crystalline penicillin } \\
19(8.63 \%)\end{array}$ & $\begin{array}{l}\text { Calcium } \\
77(8.89 \%)\end{array}$ \\
\hline 4 & $\begin{array}{l}\text { Metronidazole } \\
52(9.72 \%)\end{array}$ & $\begin{array}{l}\text { Metronidazole } \\
17(2.99 \%)\end{array}$ & $\begin{array}{l}\text { Vitamin K } \\
18(8.18 \%)\end{array}$ & $\begin{array}{l}\text { Diclofenac } \\
77 \text { (8.89) }\end{array}$ \\
\hline 5 & $\begin{array}{l}\text { Diazepam } \\
41(7.66 \%)\end{array}$ & $\begin{array}{l}\text { Ciprofloxacin } \\
17(2.99 \%)\end{array}$ & $\begin{array}{l}\text { Paracetamol } \\
17(7.72 \%)\end{array}$ & $\begin{array}{l}\text { Metronidazole } \\
77(8.89 \%)\end{array}$ \\
\hline
\end{tabular}

Among antibiotics, Ciprofloxacin (80.95\%) was the most commonly prescribed in surgery ward, Metronidazole (18.28\%) and Ciprofloxacin (18.28\%) in medicine,
Gentamicin (40\%) in pediatric and Ampicillin (73.37\%) in obstetrics and gynecology (Table 8).

Table 8: Five most frequently prescribed AMA

\begin{tabular}{|l|l|l|l|l|l|}
\hline Departments & \multicolumn{5}{|c|}{ Commonly prescribed AMAs } \\
\hline Surgery & $\begin{array}{l}\text { Ciprofloxacin } \\
(80.95 \%)\end{array}$ & $\begin{array}{l}\text { Metronidazole } \\
(49.52 \%)\end{array}$ & $\begin{array}{l}\text { Gentamicin } \\
(7.62 \%)\end{array}$ & $\begin{array}{l}\text { Ampicillin } \\
(6.67 \%)\end{array}$ & $\begin{array}{l}\text { Ampicillin } \\
\text { Cloxacillin } \\
(5.71 \%)\end{array}$ \\
\hline Medicine & $\begin{array}{l}\text { Metronidazole } \\
(18.28 \%)\end{array}$ & $\begin{array}{l}\text { Ciprofloxacin } \\
(18.28 \%)\end{array}$ & $\begin{array}{l}\text { Gentamicin } \\
(13.98 \%)\end{array}$ & $\begin{array}{l}\text { Ampicillin } \\
(12.9 \%)\end{array}$ & $\begin{array}{l}\text { Crystalline } \\
\text { penicillin } \\
(11.83 \%)\end{array}$ \\
\hline Pediatrics & $\begin{array}{l}\text { Gentamicin } \\
(40 \%)\end{array}$ & $\begin{array}{l}\text { Crystalline } \\
\text { penicillin } \\
(27.14 \%)\end{array}$ & $\begin{array}{l}\text { Ampicillin } \\
(27.14)\end{array}$ & $\begin{array}{l}\text { Cefotaxime } \\
(14.29 \%)\end{array}$ & $\begin{array}{l}\text { Amoxicillin } \\
(11.43 \%)\end{array}$ \\
\hline $\begin{array}{l}\text { Obstetrics } \\
\text { and }\end{array}$ & $\begin{array}{l}\text { Ampicillin } \\
(73.37 \%)\end{array}$ & $\begin{array}{l}\text { Metronidazole } \\
(38.69 \%)\end{array}$ & $\begin{array}{l}\text { Cefazolin } \\
(11.05 \%)\end{array}$ & $\begin{array}{l}\text { Cefalexin } \\
(6.03 \%)\end{array}$ & $\begin{array}{l}\text { Gentamicin } \\
(5.52 \%)\end{array}$ \\
\hline
\end{tabular}




\section{gynecology}

\section{Discussion}

The study of prescribing pattern is an essential component of medical audit that seeks monitoring, evaluation and necessary modifications in the prescribing practices of prescribers and help to achieve rational and cost effective medical care for the patient. Using the WHO prescribing indicators, this study has provided a better understanding of the prescribing practices in four major department of a tertiary hospital in eastern Nepal and has shown areas that need intervention.

There were more female than male patients in this study, and a majority of the patients were from Sunsari and Morang district and most of the patients were admitted to obstetrics and gynecology and surgery wards. This trend is similar to that observed in previous studies. ${ }^{8,9}$

AMA was most commonly prescribed drugs in all wards. At least one AMA was prescribed to each patient. It may reflect increased prevalence of infection and infectious diseases or irrational use of AMA. Scientific literature have reported large scale of inappropriate antibiotic use globally. ${ }^{10,11}$ Studies carried out by Hogerzeil et al in 12 developing countries reported that 47.5 to $100 \%$ of prescriptions had AMA. ${ }^{12}$ Kafle et al have reported lower value $(17.5 \%)$ AMA prescription. ${ }^{13}$ More antibiotic used may encourage development of bacterial resistance, increase cost of the treatment. Indiscriminate and inappropriate prescribing of antimicrobials is a widespread problem imposing a substantial economic burden on health care systems. The number of antibiotics prescribed should be as low as possible and should be prescribed only for bacterial diseases. There is unmet need of appropriate policy and guidelines of antibiotic uses in the hospital. It is preferable to keep the mean number of drugs per prescription as low as possible since higher figures always lead to increased risk of drug interaction. ${ }^{14}$ Reference values of 1.6-1.8 drugs per prescription is recommended by the WHO guidelines on rational use of drugs. ${ }^{15}$

In this study, mean number of prescribed drugs was 4.68. There was a variation in the average number of drugs prescribed in each wards. While patients in medicine ward received an average of 6.09 drugs, mostly gastrointestinal and AMA, patients in surgery, pediatrics and obstetrics and gynecology departments received 5.09, 3.14 and 4.35 drugs per prescription respectively. The differences in the main types of cases seen in each specialty may account for this. It was higher than the study done in Spain and Karnataka respectively. ${ }^{16,17}$ 
In our study the condition reflects polypharmacy. Previous studies have shown that polypharmacy among diabetic patients and patients with heart failure is sometimes unavoidable. ${ }^{18,19}$ Prescribing habits and the level of training of individual prescriber could also influence the number of drugs prescribed. $^{20}$ It is difficult to keep the mean number of drugs per prescription equal or below three. Polypharmacy is often associated with higher cost, increased side effects, noncompliance, and increased risk of drug interactions and errors of prescribing. Various reasons can account for this situation like ambiguity in diagnosis in a patient presenting with multiple symptoms, demand for quick relief from patient, availability of non-essential and irrational drug combination and aggressive medicine promotion.

In this study, minerals and vitamins were also prescribed group of drugs. Minerals and vitamins are important for the healing process when patients appear undernourished or when dietary patterns are inadequate especially in the elderly. It has also been reported that vitamins are sometimes prescribed as placebo where no specific indication for them exists. The benefit of prescribing vitamins in such situations is doubtful and irrational, adding to the number and cost of drugs. Vitamins are usually recommended along with oral antibiotics to prevent vitamin deficiency associated with death of normal microflora. Moreover, vitamins have more acceptance psychologically among patients bolstering their compliance (placebo effect), though; placebo therapy has been criticized as deception. $^{21}$

Most of the drugs (32.72\%) were prescribed as intravenous injections. In a recent study, $62 \%$ patients received drugs intravenously. ${ }^{22}$ The high use of injections is a matter of concern. Excessive use of injections is wasteful of scarce nursing resources and increases the risk of spread of infections.

The study here revealed all drugs were prescribed by brand names. The low percentage prescription of drugs by their generic name is responsible for the high cost of drugs to patients. In other studies, most of the drugs are prescribed by generic names. ${ }^{23,24}$ The use of generic names was also observed to be low in the two studies by the Tribhuvan University Teaching Hospital. $^{25,26} \quad 16.38 \%$ of drugs were prescribed by generic name in the study done by Upadhyay DK et al in western Nepal. ${ }^{27}$ The factor that might have contributed to the low proportion of generic drug prescription is the poor promotion of the use of generic drugs in Nepal. There is a need to improve on this as generic drug prescription has been shown to be a potential cost-effective measure in developing countries like Nepal. Thus, there is a huge scope in reducing the 
cost prices by prescribing drugs by their generic names, so that cheaper alternatives from pharmacies may be obtained, without a compromise on its quality. Therefore much emphasis should be placed on a costeffective therapy by prescribing generic drugs. Excess of prescribing by brand names may be considered as evidence of vigorous promotional activities by pharmaceutical companies. Prescribing medicines by generic name avoid the confusion and makes therapy rational and cheaper. Moreover in the teaching institutions world over, in textbooks, in scientific journals and in the research publications, medicines are always mentioned by generic names. Despite this, most doctors prescribe the medicines by their brand names. The reason for this could be tradition, aggressive medicine promotion and availability of multi-ingredient fixed dose drug combination.

The proportion of drugs prescribed from Essential drug list was low. Only $70.61 \%$ of drugs are prescribed from the Essential Drug List of Nepal. ${ }^{28}$ In other studies more drugs are prescribed form the Essentials drug list. ${ }^{23}$ Naziya Y. Mirza et al found $77.61 \%$ medicines prescribed were essential. ${ }^{29}$ $57.70 \%$ of essential medicines were prescribed in a study conducted by Mohanty BK et al. ${ }^{30}$ Though the Essential drug list was mainly developed for primary health care facilities, prescribing of Essential drugs should be encouraged. Efforts should be made to develop a hospital formulary.

This study reveals that more analgesics were also prescribed commonly. It may be due to symptomatic treatment of pain. Gastrointestinal drugs were also commonly prescribed in this study period. It may due more prevalence of acid peptic disease.

\section{Limitation}

This study was limited to an academic practice that may differ from community practice settings. Besides the prospective data sample is small and duration of study is short. However this study can form a basis for future studies with larger number of patients followed up for a longer duration of time and which will be reflective of a full population. This study was also limited to only one center hence the result cannot be generalized.

\section{Conclusion}

The poly pharmacy of AMA appears to be alarmingly high which predict prolong patients' hospital stay. Preferred intravenous route of administration and low generic prescription of drugs reflect the potential for higher proportions of inappropriate prescription of antimicrobials with ample scope for intervention to improve antimicrobial use in the hospital. It is important that doctors and other health care workers who are involved in patient care be 
educated and encouraged to practice rational drug prescribing. There is a need for periodic audit of prescribing practices to assess the success or otherwise of such interventional programmes.

\section{References}

1. IOCU: Towards rational use of drugs; prescribing of the international consultation on rational drug use in undergraduate medical/pharmacy education, International Organization of Consumers Union, Manila; Philippines, 13-18 August 1998.

2. Patel V, Vaidya R, Naik D, Borker P. Irrational drug use in India: A prescription survey from Goa. J Postgrad Med 2005; 51(1): 9-12.

3. Tripathi KD. Aspects of pharmacotherapy; clinical pharmacology and drug development. In: Essentials of medical pharmacology. 6th edition. New Delhi: Jaypee Brothers 2008;68- 71.

4. Introduction to drug utilization research/WHO International Working Group for Drug Statistics Methodology, WHO Collaborating Centre for Drug Statistics Methodology, WHO Collaborating Centre for Drug Utilization Research and Clinical Pharmacological Services. Geneva: World Health Organization; 2003; 8-12.
5. Laporte JR, Porta M, Capella D. Drug utilization studies: A tool for determining the effectiveness of drug use. $\mathrm{Br} \mathrm{J}$ Clin Pharmacol 1983; 16: 301-4.

6. How to investigate drug use in health facilities. Selected drug use indicators, WHO/DAP/93.1 World Health Organization Geneva 1993.

7. WHO. Drugs and Therapeutics Committees - A Practical Guide, World Health Organization; 2003.

8. Shankar RP, Partha P, Shenoy NK, Easow JM, Brahmadathan KN. Prescribing patterns of antibiotics and sensitivity patterns of common microorganisms in the Internal Medicine ward of a teaching hospital in Western Nepal: a prospective study. Ann Clin Microbiol Antimicrob 2003; 2:7.

9. Shankar PR, Partha P, Dubey AK, Upadhyay DK, Mishra P. Drug utilization in medical inpatients. J Nepal Health Res Counc 2006; 4:56-62.

10. Akter SFU, Rani MFA, Rahman Jab, Nordin MS, Satwi S, Awang MB et al. Antimicrobial use and factors influencing prescribing in medical wards of a tertiary care hospital in Malaysia. International Journal of science, Environment and Technology 2012. 1(4): 274-284.

11. Bajracharya S, Pandey S, Shakya YL. Drug prescribing pattern and disease 
pattern in KMC Duwakot Health Center. Kathmandu Univ Med J 2004. 2(1): 3542.

12. Hogerzeil HV, Bimo, Ross-Degnan D, Laing RO, Ofori-Adjei D, Santoso B et al. Field Tests for Rational Drug Use in Twelve Developing Countries. Lancet 1993; 342: 1408-10.

13. Kafle KK, Karkee SB, Prasad RR. INRUD Drug Use Indicators in Nepal: Practice Patterns in Health Post in Four Districts. INRUD News. 1992; 3: 15.

14. Laurence L. Brunton (Ed.). Drug toxicity and poisoning. In: The pharmacological basis of therapeutics $12^{\text {th }}$ edn. New York: McGraw-Hill Company, 2011; 7778.

15. Isah $A O$, Laing $R$, Quick J, Mabadeje AFB, Santoso B, Hogerzeil He et al. The Development of Reference Values for the World Health Organization (WHO) Health Facility Core Prescribing Indicators. West Afr J Pharmacol Drug Res 2002; 18(1 \& 2): 6-11.

16. Sanz EJ, Boada JN. Drug utilization by children in Tenerif Island, Spain. Eur J Clin Pharmacol 1998; 34:495-9.

17. JR. Torvi, S Dambal. Drug prescription pattern in pediatric outpatient clinic in a tertiary hospital. Curr Pediatr Res 2011; 15(2):77-80.
18. Good CB. Polypharmacy in Elderly patients with Diabetes. Diabetes Spectrum 2002; 15(4): 240-248.

19. Masoudi FA, Krumholz HM. Polypharmacy and comorbidity in heart failure. Br Med J 2003; 327: 513-514.

20. le Grand A, Hogerzeil HV, HaaijerRuskamp FM. Intervention research in rational use of drugs: $A$ review. Health Policy Plan 1999; 14(2): 89-102.

21. Bok $S$. The ethics of giving placebos. Sci Am 1974; 231: 17-23.

22. Shankar PR, Upadhyay DK, Subish P, Bhandari RB, Das B. Drug utilization among older inpatients in a teaching hospital in Western Nepal. Singapore Med J 2010; 51(1):28-34.

23. Enwere $\mathrm{OO}$, Falade $\mathrm{CO}$, Salako BL. Drug prescribing pattern at the medical outpatient clinic of a tertiary hospital in southwestern

Nigeria. Pharmacoepidemiol Drug Saf, 2007; 16(11):1244-9.

24. Sarkar C, Das B, Sripathi $H$. Antimicrobial drug use in dermatology in a teaching hospital in western Nepal. Int J Clin Pract 2002; 56(4):258-60.

25. Joshi MP, Sugimoto $T$, Santoso B. Geriatric prescribing in the medical wards of a teaching hospital in Nepal. Pharmacoepidemiol Drug Saf 1997; 6:417-21. 
26. Lohani SP, Thapa P, Aryal UR, Satyal KR. Polypharmacy and geriatric patients: patterns of prescribing in the Tribhuvan University Teaching Hospital in Nepal. J Nepal Health Res Counc 2006; 4:1-4.

27. DK Upadhyay, S Palaian, PR Shankar, $P$ Mishra. Rational drug prescribing and dispensing in tertiary care teaching hospital of Western Nepal. J Inst Med 2008; 30:2:33-38.

28. National List of Essential Medicines Nepal, Fourth Revision, 2011. Department of Drug Administration (DDA), Nepal; Accessed on July 9,
2013-

http://www.dda.gov.np/druglist/nlem201

1.pdf

29. Nazima Y. Mirza,Sagun Desai, Barna Ganguly. Prescribing pattern in a pediatric out-patient department in Gujarat. Bangladesh J pharmacol 2009; 4:39-42.

30. Mohanty BK, Ashwini M, Hasamnis AA, Patil SS, Murty KSN, Jena SK. Prescription pattern the department of a tertiary care hospital in Rajamundry, India. Journal of Clinical \& Diagnostic Research 2010; 4: 2047-51. 